\title{
Isolation of Cellulose Fiber from Water Hyacinth (Eichornia crassipes) by Bleaching-Alkalination Method
}

\author{
Nur Hidayah ${ }^{[1]}$, Ikna Urwatul Wusko ${ }^{2}$ \\ \{nurhidayah@unism.ac.id ${ }^{1}$,iknaurwatulwusko@unism.ac.id² $\}$
}

\begin{abstract}
${ }^{1}$ Department of Information System, Faculty of Sains and Technology, Sari Mulia University, Banjarmasin, Kalimantan Selatan, ${ }^{2}$ Department of Industrial Engineering, Faculty of Sains and Technology, Sari Mulia University, Banjarmasin, Kalimantan Selatan
\end{abstract}

\begin{abstract}
The growth of water hyacinth (Eichornia crassipes) as weeds of floating aquatic plants occurs so fast that it is often regarded as waste. Water hyacinth that develops rapidly in the aquatic environment can cause environmental damage and can be one of the factors causing floods. Behind the negative assumption that water hyacinth is a plant that is rich in natural fiber content, namely cellulose. This study aims to characterize the content in water hyacinth and cellulose fiber insulation using an alkali method. By using SNI 01 2891.1992 as a characterization procedure, values of water content, fat content, crude fiber content, ash content, protein content and carbohydrate content for water hyacinth plants in Banjarmasin waters were respectively. While cellulose fiber insulation results by $53,45 \%$, lignin $24,43 \%$ and hemicellulose $22,12 \%$.
\end{abstract}

Keywords: Please list your keywords in this section.

\section{Introduction}

Water hyacinth is a weed plant that belongs to the family Pontederiaceae. Water hyacinth has thick oval-shaped leaves with a fresh green color and shiny when exposed to sunlight [1]. The leaves are supported by cylindrical stems extending to lengths up to 1 meter and $1-2 \mathrm{~cm}$ in diameter [2]. The water hyacinth stalk has strong, weak fibers and contains a lot of water. Water hyacinth can live free floating on the surface of the water and rooted in the bottom of a pond or swamp with shallow water [3]. Nutrition for its development is obtained by sucking water and vaporizing it back through the leaves of plants exposed to the sun through the evaporation process. So to be able to grow water hyacinth is very dependent on the presence of sunlight and the availability of water [4]. 


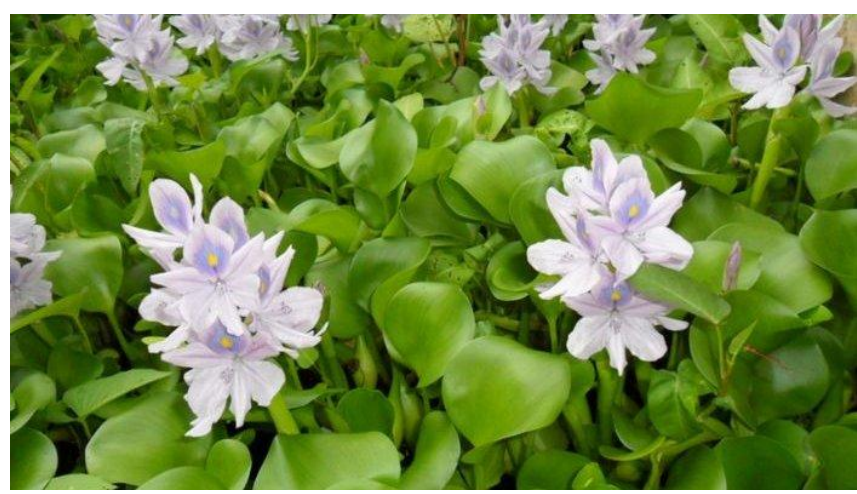

Fig 1. Water hyacinth (Eichornia crassipes)

Water hyacinth plants have a fast regeneration power. Hyacinth breeding can be done in two ways, namely vegetatively and generatively. Breeding vegetatively can multiply in 7-10 days [5]. Very fast breeding of water hyacinth causes environmental problems and river activities such as blocking water traffic, decreasing river water discharge, reducing the amount of light entering the waters which causes a decrease in the level of dissolution of oxygen in water and accelerating the silting process. The population of water hyacinth that disturbs water areas can be reduced by utilizing water hyacinth fibers as raw material for ethanol $[6,7,8]$ and high caloric fuel [9]. Pretreatment of water hyacinth stems with $10 \% \mathrm{NaOH}$ for 1 hour at $100^{\circ} \mathrm{C}$ can convert cellulose by $60.35 \%[10,11]$. In addition, the use of se as a raw material for paper is also a water hyacinth stalk that has been mixed with pulping process [12]

\section{Research Method}

The methodology used in this study followed the sample testing procedure with SNI number 0128911992 including testing the water content, ash content, protein, fat, crude fiber, carbohydrate content [13].

\subsection{Water Level}

Dishes that have been cleaned and dried in an oven at $105^{\circ} \mathrm{C}$ for 15 minutes are cooled in a desiccator, then weighed. The sample was weighed as much as 5 grams and put in the cup. The cup that has been filled in the sample is then put into an oven at $105^{\circ} \mathrm{C}$ for 6 hours. The cup is removed from the oven and cooled in a desiccator then weighed. If the weight is still changing, then drying is repeated with the same temperature and time. Drying is carried out 3-4 times or more until a constant weight is obtained as the final weight of the sample. Water content can be calculated based on weight loss, which is the difference between the initial weight of the sample and the final weight of the sample, using the formula:

$$
\text { water level }(\%)=\frac{a-b}{a} \times 100 \%
$$

explanation:

$\mathrm{a}=$ Initial sample weight $(\mathrm{gram})$

$\mathrm{b}=$ Final sample weight (gram)

\subsection{Fats level}

Samples from the water content analysis were weighed in filter paper, then installed in a soxhlet flask and condenser. Reflux is done with a fat solvent for 5 hours. After that, the sample is removed from 
the soxhlet flask, dried and cooled in a desiccator. Then weighed until the weight is constant. Fat content is calculated using the formula:

$$
\text { fats level }(\%)=\frac{a-b}{w} \times 100 \%
$$

explanation:

$\mathrm{a}=$ weight of sample + filter paper before extracting (gram)

$\mathrm{b}=$ weight of sample + filter paper after extracting (gram)

$\mathrm{w}=$ sample weight (gram)

\subsection{Ash level}

The sample is weighed as much as $2-3$ grams, then put into a porcelain cup that has a known permanent weight. Samples were arranged on a heater and then blended in an electric furnace at $550^{\circ} \mathrm{C}$ for 5-6 hours until complete graying. The cup is then cooled in a desiccator, then weighed to a fixed weight. Ash content can be calculated using the formula:

$$
\text { ash level }(\%)=\frac{w_{1}-w_{1}}{w} \times 100 \%
$$

explanation:

$\mathrm{w}=$ sample weight before burned (gram)

$\mathrm{w}_{1}=$ weight of sample + cup after burned (gram)

$\mathrm{w}_{2}=$ weight of empty cup (gram)

\subsection{Protein}

A sample of 0.1 gram was put into the Kjeldahl flask. The catalyst weighed as much as 1 gram consisting of $\mathrm{CuSO}_{4}$ : $\mathrm{Na} 2 \mathrm{SO} 4=1$ : 1.2 . Subsequently added $2.5 \mathrm{ml}$ of concentrated $\mathrm{H}_{2} \mathrm{SO}_{4}$ and decollated until the liquid is clear green, extraction is continued for 30 minutes. The pumpkin and its contents are cooled to room temperature, then the contents are transferred to a distillation apparatus and $15 \mathrm{ml}$ of $50 \%$ $\mathrm{NaOH}$ is added (until the solution becomes basic). The distillates are stored in a $200 \mathrm{ml}$ Erlenmeyer containing $0.02 \mathrm{~N} \mathrm{HCl}$ until not less than $50 \mathrm{ml}$ distillate, then the results are distilled with $0.02 \mathrm{~N} \mathrm{NaOH}$ accompanied by the addition of a mensel indicator (a mixture of methyl red and methyl blue) 3-4 drops. The treatment is also carried out on blanks.

$$
\text { protein level }(\%)=\frac{a \times N \times 14 \times 6,25}{w} \times 100 \%
$$

explanation:

$\mathrm{a}=$ volume difference of $\mathrm{NaOH}$ was used to titrate a sample of blank

$\mathrm{N}=\mathrm{NaOH}$ normality

$\mathrm{W}=$ sample weight (milligram)

\subsection{The rate of coarse fiber}

A sample of 1 gram was put into a $300 \mathrm{ml}$ Erlenmeyer flask and then added $100 \mathrm{ml}$ $\mathrm{H} 2 \mathrm{SO} 40.325 \mathrm{~N}$. The material was then hydrolyzed in an autoclave at $105^{\circ} \mathrm{C}$ for 15 minutes. The material is cooled, then added $50 \mathrm{ml}$ of $1.25 \mathrm{~N} \mathrm{NaOH}$ and re-hydrolyzed in a $105 \mathrm{oC}$ temperature autoclave for 15 minutes. Material is filtered using filter paper that has been dried and its weight is known. After that the filter paper was washed successively by using hot water, $25 \mathrm{ml} \mathrm{H} 2 \mathrm{SO} 40.325 \mathrm{~N}$, hot water, then $25 \mathrm{ml}$ of acetone or alcohol. The residue and filter paper is dried in an oven at $110^{\circ} \mathrm{C}$ for 1-2 hours. Crude fiber content can be calculated using the formula:

$$
\text { the rate of coarse fiber }(\%)=\frac{a-b}{w} x 100 \%
$$

explanation:

$\mathrm{a}=$ weight of residue in filter paper that has been dried (gram)

$\mathrm{b}=$ weight of empty filter paper (gram) 
$\mathrm{w}=$ sample weight $($ gram $)$

2.6 Carbohydrates

Carbohydrates by different $=(100 \%-\%$ water level $-\%$ ash level $-\%$ protein $-\%$ fat level $-\%$ the rate of coarse fiber)

As for the characteristics of the lignocellulosic biomass content to determine the content of cellulose, lignin, hemicellulose used by the ADS and NDS methods.

\subsection{Analysis of Neutral Detergent Fiber (NDF)}

A total of 1 gram of sample (a) was put into a $600 \mathrm{ml}$ beaker and $100 \mathrm{ml}$ was added to the NDS solution then heated. The sample is extracted for 60 minutes from starting to boil. The extracted sample was filtered using a previously weighed G3 sand glass plate (b). The residue is rinsed using hot water and acetone. The glass plate and the residue are dried in a $105^{\circ} \mathrm{C}$ oven for \pm 4 hours until the weight is stable. The sample is removed and cooled in a desiccator then the cup is weighed (c).

$$
\% A D F=\frac{c-b}{a} x 100 \%
$$

\subsection{Analysis of Acid Detergent Fiber (ADF)}

The sample was weighed as much as 1 gram (A) and put into a $600 \mathrm{ml}$ beaker, then 100 $\mathrm{ml}$ was added to the ADS solution. The sample is extracted for 60 minutes from starting to boil. The liquid is filtered using a pre-weighed glass plate B (B). The residue is rinsed using hot water and acetone. The residue is dried in a $105^{\circ} \mathrm{C}$ oven for \pm 4 hours until the weight is stable. The cup is removed and cooled in a desiccator. After chilling, the cup is weighed (C). The ADF percentage can be calculated based on the following formula:

$$
\begin{gathered}
\% A D F=\frac{C-B}{A} \times 100 \% \\
\% \text { hemiselulosa }=\% N D F-\% A D F
\end{gathered}
$$

\subsection{Analysis of Cellulose}

Cellulose analysis is a continuation of ADF analysis. The ADF analysis sample that had been weighed (C) plus a 72\% sulfuric acid solution (H2SO4) until submerged for 3 hours. After 3 hours, the residue was rinsed using hot water and acetone. The residue is dried in a $105^{\circ} \mathrm{C}$ oven for \pm 4 hours until the weight is stable, remove and cool in a desiccator. After chilling, the cup is removed from the desiccator and weighed (D).

\subsection{Analysis Lignin}

$$
\% \text { selulosa }=\frac{C-D}{A} \times 100 \%
$$

Lignin analysis is a continuation of ADF and cellulose analysis. The dried sample (D) is then burned in a furnace with a temperature of $\pm 600^{\circ} \mathrm{C}$. The dishes are cooled in a desiccator and weighed $(\mathrm{E})$. The amount of lignin content is calculated using the following equation:

$$
\% \text { lignin }=\frac{C-E}{A} x 100 \%
$$




\section{Results and Discussion}

Raw materials of water hyacinth plants were obtained Barito Rivers at Banjarmasin. Based on the proximate analysis conducted on the raw materials for water hyacinth plants sample, are given below in table. 
Table 1. Characterization of water hyacinth plants sample

\begin{tabular}{ll}
\hline Composition & Results (\%) \\
\hline Water level & 28,3 \\
Ash level & 3,25 \\
Protein & 2,35 \\
Fat level & 3,12 \\
The rate of coarse fiber & 36,65 \\
carbohydrate by different & 37,47 \\
\hline
\end{tabular}

Based on the results obtained in table 1 it can be seen that the water hyacinth plants has a moisture content of $14.53 \%$. The water content in water hyacinth plants comes from the boiling process with a steam system from the factory which causes the water hyacinth plants to become saturated with water during the boiling process. The value of excess water content can reduce the heating value of the OPEFB fiber. This can hamper the combustion process so that it is not good if used as fuel.

Basically, water hyacinth plants does not contain oil because oil is only produced in palm fruit. But the results of proximate analysis showed a fat content of $2.13 \%$. The oil contained in OPEFB comes from oil palm fruit which is absorbed into the cell wall through the OPEFB fibers by osmosis during the boiling process and the process of shelling of FFB. Besides containing water and fat, OPEFB waste also contains protein and ash content. Respectively $4.35 \%$ and $4.87 \%$.

The largest proximate content is crude fiber and carbohydrates, $36.65 \%$ and $37.47 \%$. The large fiber and carbohydrate content causes water hyacinth plants also known as lignocellulosic biomass. Water hyacinth plants fiber has three main ingredients, namely cellulose, hemicellulose, and lignin. Cellulose which has the molecular formula (C6H10O5) $n$ is a long-chain linear glucose polymer that is connected by glycosidic $\beta(1,4)$ bonds. Based on testing conducted by the NDS and ADS solution method it is known that the cellulose content in the OPEFB PT. KAP of $55.75 \%$ as given in table 2. In the structure of plant cell walls, cellulose binds to hemicellulose and lignin. In this analysis test, the amount of lignin and hemicellulose were obtained $28.93 \%$ and $15.32 \%$, respectively. Lignin physically encloses microfibril cellulose in a hydrophibric matrix and is covalently bonded to both cellulose and hemicellulose.

At present, cellulose is considered as an alternative material that can be used to make environmentally friendly products in various fields of application. Its abundant and renewable availability makes cellulose even more potential to be developed. Based on the results of proximate characteristics tests conducted on palm oil palm empty fruit bunches waste from PT. Kharisma Alam Persada can be seen that this waste is very potential to be used for product applications. The TTKS characteristic values presented may differ from one source to another depending on age, size, growth phase, geographical location, soil conditions, climatic influences for oil palm growth in the field and the testing methods used.

Table 2. Characterization of fiber's water hyacinth plants sample

\begin{tabular}{ll}
\hline Composition (\%) & Water hyacinth plants \\
\hline Water level & 24,43 \\
Ash level & 22,12 \\
carbohydrate by different & 53,45 \\
\hline
\end{tabular}




\section{Conclusion}

Based on characterization testing using SNI 0128911992 method on water hyacinth plants is known that the content of crude fiber and carbohydrates by different are $36.65 \%$ and $37.47 \%$, respectively. The highest content value compared to other compositions such as water content or fat content, ash content and protein. Testing the composition of the fibers in water hyacinth plants produces data on cellulose, lignin and hemicellulose content, respectively at 55.75\%; $28.93 \%$ and $15.32 \%$. The high cellulose content of water hyacinth plants has the potential to be used as raw material for hidrogel.

\section{References}

[1] Septiana, T. Pengaruh Konsenstrasi Saccharomyces Cerevisiae Pada Fermentasi Eceng Gondok (Eichornia Crassipes Solms.) Terhadap Produksi Bioetanol Sebagai Bahan Pengayaan Praktikum Mikrobiologi Terapan. Jurnal Pengaruh Konsenstrasi Saccharomyces cerevisiae Pada Fermentasi Eceng Gondok (Eichornia crassipes Solms.) Terhadap Produksi Bioetanol Sebagai Bahan Pengayaan Praktikum Mikrobiologi Terapan. (2019)

[2] Samsudin, A., \& Husnussalam, . IbM Pemanfaatan Tanaman Eceng Gondok (Eichornia crassipes) untuk Kerajinan Tas. Agrokreatif Jurnal Ilmiah Pengabdian kepada Masyarakat, 3(1), 34-39. (2017).

[3] Abdel-Fattah, A. F. and M. A. Abdel-Naby. "Pretreatment and enzymic saccharification of water hyacinth cellulose”. Carbohydrate Polymers, 87. 2109-2113. 2012.

[4] Kumar, A, L.K. Singh and S. Ghosh. "Bioconversion of Lignocellulosic Fraction of Waterhyacinth (Eichhornia crassipes) Hemicellulose Acid Hydrolysate to Ethanol by Pichia stipitis", Bioresource Technology, 100. 3293-3297. 2009.

[5] Alisyahbana, R. Pengolahan Air Limbah Sablon Mengunakan Metode Kombinasi Bak Berjenjang Dengan Tanaman Eceng Gondok (Doctoral dissertation, Universitas Muhammadiyah Surakarta). (2019).

[6] Gunawan, P. dan Sahwalita. Pengolahan Eceng Gondok sebagai Bahan Baku Kertas Seni. Balai Litbang Kehutanan Sumatera, Medan. 2007.

[7] Prihatiningtyas, S., Sholihah, F. N., \& Nugroho, M. W. Peningkatan Pemahaman Dan Keterampilan Masyarakat Dalam Memanfaatkan Limbah Cair Tahu Sebagai Biogas Di Dusun Bapang Kabupaten Jombang. Jurnal Abdimas BSI: Jurnal Pengabdian Kepada Masyarakat, 3(1), 102-108. (2019).

[8] Lu, W., C. Wang and Z. Yang. "The preparation of High Caloric Fuel (HCF) from Waterhyacinth by Deoxyliquefaction”, Bioresource Technology, 100. 6451-6456. 2009.

[9] Maria Amanda Matrosya, M. Perbandingan Efektivitas Fitoremediasi Menggunakan Tanaman Kayu Apu (Pistia Stratiotes) Dan Eceng Gondok (Eichornia crassipes) Dalam Mereduksi Besi (Fe) Dan Mangan (Mn) Serta Meningkatkan Nilai Derajat Keasaman (Ph) Pada Limbah Logam Balai Labkesda Prov. Banten (Doctoral Dissertation, Universitas Sahid). (2020).

[10] Nurhilal, O., Suryaningsih, S., Faizal, F., \& Sharin, R. Pemanfaatan Eceng Gondok Sebagai Adsorben Pb Asetat.

[11] Rorong, J. A., \& Suryanto, E. Analisis fitokimia enceng gondok (Eichhornia crassipes) dan efeknya sebagai agen photoreduksi $\mathrm{Fe}^{3+}$. Chemistry Progress, 3(1), 33-41. (2019). 
[12] Yoniza, Y., \& Mahyudin, A. Analisis Pengaruh Komposisi Serat Pinang dan Serat Eceng Gondok terhadap Sifat Mekanik Komposit Hibrid Polipropilena dengan Pati Talas. Jurnal Fisika Unand, 9(1), 24-30. (2019).

[13] Lestari, Ayu Faiza. Pembuatan hIdrogel Nanofiber Selulosa Dari Tandan Kosong Kelapa Sawit (TKKS). Departemen Teknologi Industri Pertanian. Institut Pertanian Bogor. 2016. 